sarily erupted, as previously thought, through dykefissures.

Finally, it should be recorded that the history of 250 years investigation is most entertainingly sum. marized and fully documented. By his outstanding success in grappling with a group of problems that has tantalized many generations of "Inquisitive Naturalists", Mr. Tornkeieff has far outdistanced his predecessors. $\mathrm{He}_{\theta}$ is to be congratulated on a contribution which, for the first time in the history of the Causeway, may be hailed as thoroughly worthy of its impressive subject.

Arthur Holmes.

${ }^{2}$ Tomkeieff, S. I., Bull. Volcanologique, ii, 6, 89 (1940).

${ }^{2}$ Holmes, A., Proc. Roy. Irish Acad., 43 B, 91 (1936).

\section{THE FILM IN SCIENCE}

A CONFERENCE on "The Film in Science", organized by the Scientific Film Association, was opened at the Technical College, Huddersfield, on August 31, after a civic reception by the Mayor, Alderman Sidney Kaye; over 100 were present.

Mr. Geoffrey Bell (deputizing for Mr. Arthur Elton, president of the Association, who was in Denmark) said that the conference gave an opportunity for many different users of scientific films to state their needs and problems. That the Conference was held in the provinces implemented the Association's aim to be fully representative of Britain rather than metropolitan in character. The Scientific Film Association could bring to a focus the growing scientific culture partly represented by scientific film societies all over Britain-and also shown, significantly, by the chance that the B.B.C. on the following Sunday was broadcasting its first review of scientific films. He added that the pressure of events has now made it clear that a widespread understanding of what science stands for, long recognized as desirable, is a matter of the most vital necessity; and films can help to bring about this understanding.

Miss Dorothy Grayson (educational representative of the British Film Institute), speaking on "The Science Film in Education", said that one of the duties of science is to protect people from making blind assumptions. Films should fall into threo categories: those which deal with the established. sciences; those presenting the facts as known, with some attempt to derive conclusions from them; and those which give education in doctrines and values. "We always pretend," said Miss Grayson, "that schooling contains no element of propaganda, but we should be wiser if we faced the realization that it does. We try to pretend that we as teachers deal only with the facts, and that our own personalities and convictions never seep through. This is not true. The children do get their values very largely from environment, but these also come from the deliberate purposive education given in schools. Instruction and practice in critical deduction is very necessary." In school the film is especially valuable as a tool of exposition. The screen can bring into juxtaposition events separated in time and space, it benefits research inquiry by adjusting time- and sight-scales, and it makes history a living thing. The films also present the teachers' factual material in ampler form and leave them free to concentrate on interpretation. There should be abolition of customs duties on all educational films which merit international circulation, and a subsidy for the development of such work is also badly needed.
On the morning of September 1, Mr. W. F. Andrews (head of the Department of Chemistry, Physies and Biology, Doncaster Technical College), speaking on "Scientific Film Needs in Technical Training", said that from many years of experience he realized the need for three types of film covering the requirements of primary, secondary and advanced technical training. Mr. H. Richmond (head of the Mining Department, Doncaster Technical College) described the "Film Strip in Technical Training", emphasizing its value for revision purposes. He showed a strip which has been used as an introductory aid for acclimatizing mining trainees to pit work. Both speakers stressed the need for an immediate supply of such visual material, the value of which was demonstrated during the War in technical training for the Services.

In the afternoon, the use of the "Film as an Instrument of Scientific Research" was described and demonstrated by Mr. Derek Stewart (Kodak Research Laboratories). After a short historical account of the technical development of cinematography, he dwelt at some length on the various ways in which the modern camera has been perfected for specialized purposes. High speed enables as many as 3,000 exposures per second to be taken. Reductions in apparent speed of up to 200 to 1 are therefore obtainable when projecting such pictures at the normal rate. This technique has made valuable contributions to the analysis of motion of rapidly moving machinery and to the study of the mechanism of explosions. At the other end of the scale, time-lapse photography, used to such fine purpose by the late Percy Smith, has served to speed up the apparent rate of motion of slow-moving processes. Biological growths, for example, taking many months in reallife, can thereby be presented visually and as a homogeneous whole in the space of a few minutes.

In the evening, Mr. Basil Wright (producer at the Crown Film Unit) talked on "Film Production". He emphasized that the new art of the film is only possible through the co-operation of many workers skilled in different spheres. Even if the exceptional man did all his own scripting, directing and cutting, he would be almost certain to have his processing done commercially. In the professional field, this means that film-making demands highly developed team-work. One aspect of this is the relationship between director and producer, best explained perhaps by saying that the producer has to see the wood while the director looks for the trees. In subsequent discussion, the need for instruction in film-making was emphasized. Medical men and scientific men would thereby be enabled to produce film records valuable as a means of exchanging ideas and imparting information. The existence at the University College, Exeter, of the first Visual Education Centre in Britain is a significant step towards academic recognition.

There followed a reading, in his absence, of a paper by Mr. Frank Goodliffe (director of Science Films) on the making of that most valuable part of the scientific film, the animated diagram. This was illustrated by the screening of one of his films.

On September 2, under the chairmanship of Surgeon Lieut.-Cmdr. R. C. MacKeith (chairman of the Medical Committee of the Scientific Film Association), there was a discussion on "The Film in Medicine", together with a show of films on public health and of specialized films for medical men and medical students. The need for presenting each sub- 
ject from many different angles and in the light of opposing schools of thought was stressed by a delegate from South Wales, supported by many others. After seeing the film "Defeat Tuberculosis", he said that, admirable though it was in showing the cure of the disease under ideal clinical conditions, it might nevertheless lull the public, to whom it was designed to be shown, into a false sense of security. Apart from allaying the fear of 'T.B.' in the public mind, it should also have emphasized the urgent necessity for providing the ideal facilities to all who may be in need of them.

The value of the film in teaching medicine, and in particular, surgery, was demonstrated by a professionally made film on "Transplantation of Cornea Autokeratoplasty", as well as by an amateur production by three medical men from the Westminster Hospital on an "Introduction to Acute Inflammation".

Dr. W. T. Astbury (director of the Textile Physics Laboratory, University of Leeds) gave a lecture on "X-Ray Adventures among the Proteins and other Molecular Giants" on September 2. In this talk, garnished with a pleasant humour and illustrated by slides and 'working' models of proteins and fibre molecules, Dr. Astbury emphasized his conviction that the mere imparting of knowledge is not enough. Films should be made which show the quest for ultimate knowledge to be a dramatic and exciting adventure.

During the Conference, delegates inspected an exhibition of projectors and other visual aid equipment; spare projectors were kept busy running amateur-made films, and film strips. The scientific film review, broadeast in the Sunday evening "Science Magazine", interested many. Discussions followed. all the lectures, and the Conference ended with a long programme of scientific films.

The Scientific Film Association will publish a full account of the proceeckings as soon as possible.

\section{TYROGLYPHID MITES AND HUMAN DISEASE}

$\mathrm{S}$

TUDENTS of applied zoology are familiar with the damage caused by Tyroglyphid mites to stored products valuable to man. The part they may play in the causation of disease is less well known.

Sir Philip Manson-Bahr and W. J. Muggleton (Lancet, 81, Jan. 20, 1945) direct attention to the possible significance of mites and their eggs in human fæces. Invasion of the human alimentary, urinary and respiratory tracts by tyroglyphid-and sometimes also by tarsonemid-mites has been reported by M. Khalil (Proc. Roy. Soc., Med., 14, Sect. Trop. Dis., 24 ; 1921), who found the eggs of Aleurobius farince in 8 per cent of 130 Cornish miners; by J. Mackenzie (J. Roy. Army Med. Corps, 39, 339 ; 1922), who found $A$. farince and Tarsonemus in recruits suffering from nocturnal enuresis and in one suffering from hæmaturia; and by others who found various mites in human sputum. The evidence about the possible effects of mites in the human alimentary canal has been reviewed up to 1929 by A. Hase (Z. Parasitenkunde, 1, 765; 1929). Some experts think that such common mites as Glyciphagus domesticus, Aleurobius farinoe (in meal) and the cheese mites Tyroglyphus siro and $T$. longior can be pathogenic if great numbers are eaten; others deny this. The dermatitis suffered by people who handle mite-infested foodstuffs (Grocer's itch, copra itch) is, however, well known (see Lancet, 351, Sept. 9, 1944). Manson-Bahr has seen dead mites in human fæces from time to time, and during the past year has been finding them with increasing frequency. Recently, eggs showing development from the morula stage to the newly hatched nymph have been found in the fæces of two patients. The mites could not be identified with certainty, but were probably Tyro. glyphus siro. One of the patients had had recurrent diarrhoea and had come from the Isle of Man, where he had eaten much over-ripe cheese. Search for similar mites in the rationed cheese now being sold in Britain has failed. Manson-Bahr and Muggleton conclude that, so far as can be ascertained at present, the presence of mite eggs in human fæces has no pathological significance.

The possible effects of mites upon the respiratory tract are the subject of a paper by E. Soysa and M. D. S. Jayawardena (Brit. Med. J., 1, Jan. 6, 1945) on pulmonary acariasis. During 1943-44 these authors observed a remarkably heavy incidence of bronchial asthma among patients in a hospital of the South-East Asia Command. From January 1942 until June 1944 bronchial asthma was responsible for 48 per cent of all respiratory cases and for 21 per cent of cases invalided out of the Army through this hospital. Some patients showed a high eosinophilia, which in asthma may be, according to Osler, as high as 53 per cent. But the patients rarely gave a family history of asthma or of other allergic symptoms; their eosinophilia was not due to intestinal parasites; drugs commonly given to relieve asthma gave only temporary relief to these patients, and their eosinophilia persisted. Major T. R. Jansen referred the authors to a civilian patient who had asthma with high eosinophilia, and mites were found. in his sputum; he made a remarkable recovery after administration of pentavalent arsenic. Referring to the work in Ceylon of H. F. Carter, G. Wedd and V. St. E. D'Abrera (Ind. Med. Gaz., 79, 163; 1944), who recovered species of Tyroglyphus, Tarsonemus, Carpoglyphus, Glyciphagus and Cheyletus, all common in stored products, dust, debris, etc., from 17 out of 28 patients, and found that arsenical treatment reduced both the numbers of the mites and the eosinophilia, Soysa and Jayawardena record their own observations.

The whole problem and its relevant literature is discussed by Soysa and Jayawardena, who found, as others have done, that treatment with arsenical preparations (they used 'carbasone' or 'stovarsol') was satisfactory. While the existing evidence does leave some doubt whether mites can alone cause all the asthma-like symptoms described, the problem requires further investigation. The differential diagnosis between this asthma-like condition and tuberculosis and other obscure and transient respiratory conditions with asthma-like symptoms and eosinophilia (for example, Loeffler's syndrome) may be especially difficult.

That monkeys of the genus Macacus suffer from pulmonary lesions in which mites are found is shown by L. J. Davis (Brit. Med. J., 482, April 7, 1945), who quotes F. D. Weidman (J. Parasit., 2, $37 ; 1915)$ on the acarids which he found in the lungs of Macacus rhesus. Davis found in the lung lesions of a species of Macacus (the species is not stated) mites which probably belonged to the genus Pneumonyssus, and he suggests that these mites may be 